\author{
Borislav STOJKOV \\ Snežana SUBOTIĆ
}

\title{
Strateški cilji razvoja Beograjske metropolitanske regije $v$ okviru evropskega prostorskega razvoja
}

\begin{abstract}
Pomembnost Beograda je zaradi znanih razlogov $\checkmark$ zadnjem desetletju resno nazadovala. Za prihodnji razvoj $v$ zdaj spremenjenih okoliščinah je zato treba opredeliti nekaj prednostnih strateških ciljev. V prispevku so predstavljeni najpomembnejši, in sicer: nova opredelitev in postavitev metropolitanske regije $v$ odnosu do evropskega, makroregionalnega in regionalnega zaledja oziroma njen položaj in vloga/funkcija $v$ evropskem in balkanskem okviru, vzpostavitev učinkovite in vzdržne prometne infrastrukture in ustrezne vključitve $v$ evropsko prometno omrežje, dekoncentrirana koncentracija in prestrukturiranje, izboljšanje in razmestitev ekonomskih struktur zaradi povečanja ekonomske konkurenčnosti metropolitanske regije, varovanje in izboljšanje naravnih osnov, kulturnih posebnosti in krepitev metropolitanske identitete ter profiliranje beograjske metropolitanske regije prek specializiranih gospodarskih dejavnosti, še posebno storitvenih dejavnosti za jugovzhodno Evropo.
\end{abstract}

\section{Uvodno razmišljanje}

Specifična okoliščina resnega nazadovanja Srbije konec 20. stoletja je pustila posledice tudi v razvoju glavnega mesta Beograda. Glede na sorazmerno pomembnost in velikost tega mesta $v$ evropskem okviru, lahko sklepamo, da je takšno zaostajanje zares imelo izhodišče v političnih okoliščinah, saj vse vodilne zamisli in strateške poteze praviloma nastajajo v dominantnem središču moči. Spodbujeno s Prostorskim planom Republike Srbije (sprejet leta 1996) je tudi mesto Beograd v sodelovanju z Republiko Srbijo leta 2003 začelo izdelovati Regionalni prostorski plan mesta Beograd, z naslednjimi nalogami:

- ustaviti pošastno gospodarsko zaostajanje;
In the last decade the importance of Belgrade has for known reasons seriosly deteriorated. For future development under the new circumstances it is therefore necessary to define several primary strategic goals. In this article the most important ones are presented, namely: new definition and positioning of the metropolitan region in relation to the European, macro-regional and regional hinterland or its position and role/function in the framework of Europe and the Balkans; establishment of efficient and sustainable transport infrastructure and adequate inclusion in the European transport system; deconcentrated concentration and restructuring; improving and placing economic structures for increasing economic competitiveness of the metropolitan region; protection and improving natural givings, cultural specifics and strengthening the metropolitan identity, as well as profiling the Belgrade metropolitan region with specialised economic activities, especially service activities oriented towards south-eastern Europe.

- omiliti najizrazitejše socialne probleme, ki jih povzroča nenadzorovano priseljevanje beguncev in razseljenih oseb s prostora bivše SFRJ;

- sanirati resno ogroženo gospodarsko integriteto poseljenega in neposeljenega prostora mesta Beograd, ki obsega $3224 \mathrm{~km}^{2}$ in 1.618.000 prebivalcev, živečih v sedem urbanih središč in prek 130 podeželskih naselij.

Regionalni prostorski plan mesta Beograd je bil sprejet v letu 2004. Postavil je osnovne smernice prostorskega razvoja ob upoštevanju tekočih prednostnih nalog, in sicer:

- zaščito in kakovostno nadgraditev evidentiranih razvojnih virov in vrednot;

\section{Beograd \\ Beograjska metropolitanska regija Jugovzhodna Evropa Regionalno planiranje Srbija \\ Belgrade \\ Belgrade metropolitan region \\ Regional planning Serbia South-eastern Europe}


- pravno, ekonomsko in fizično ureditev vsega prostora mesta Beograd;

- zagotoviti vzdržen prostorski razvoj ključnih funkcij in komunikacij.

Značaj Strategije prostorskega razvoja je očitno ofenziven, kar pomeni predvsem okrepitev ključnih vzvodov sistema in potem širitev v regionalnem zaledju. Osnovne planske rešitve so zato obravnavane regionalno (soodvisno z zalednimi občinami) in transregionalno, torej prek funkcij in interesov, ki jih mesto Beograd kot regija veže na druge evropske regije. Dejstvi, da je Beograd konec prejšnjega stoletja izgubil vlogo evropske metropole z izključitvijo iz procesa evropskih integracij in sodelovanja ter da je v istem obdobju postal središče državne in republiške uprave nove države, pri tem pa izgubil veliko gospodarske moči in urbane identitete, sta usmerili oblikovalce zasnove novega plana k osnovnemu cilju, ki je: organiziranje regionalnih prostorskih potencialov, s katerimi bi povečali privlačnost mesta in do leta 2011 zagotovili razmere za doseganje standarda evropske metropole. Pri oblikovanju strategije in planskih rešitev $\mathrm{v}$ tem regionalnem planu je zato obravnava položaja in vloge mesta Beograd v širšem evropskem okviru še posebno pomembna. Za zasnovo strateških ciljev metropolitanskega območja Beograda je bilo torej nujno začeti pri dejanskih danostih, možnostih in potencialih glede na splošne evropske, makroregionalne in regionalne težnje razvoja.

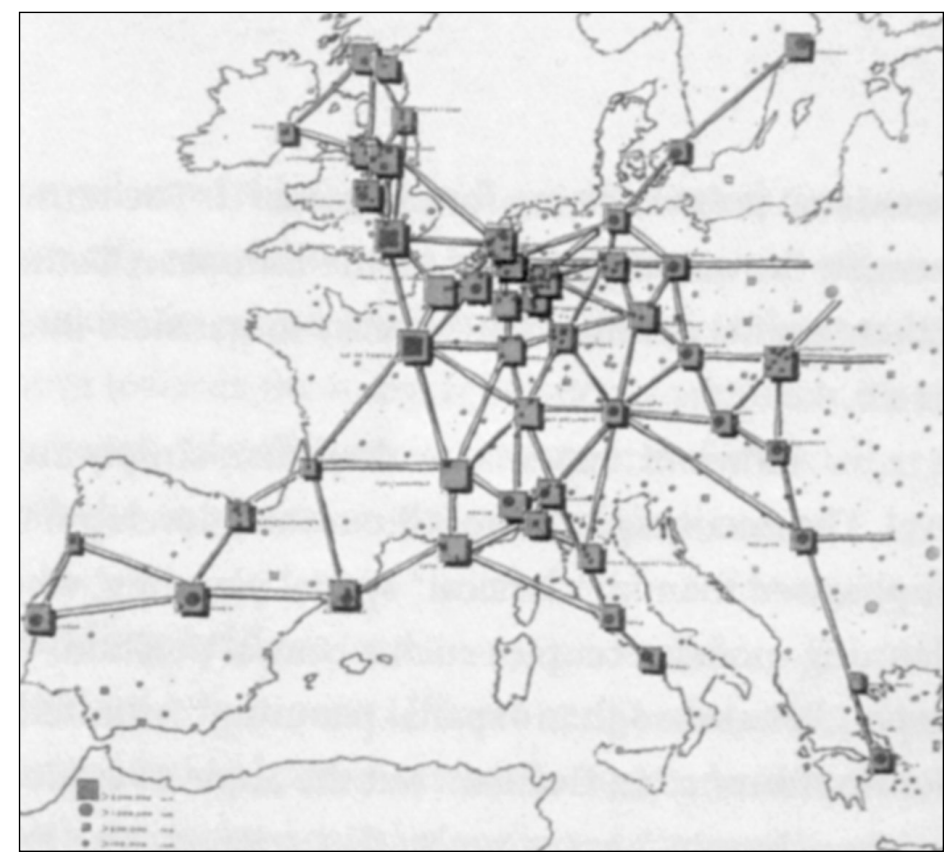

Slika 1: Evropska urbana mreža po RPD iz leta 1991.

\section{Osnovna strateška izhodišča}

Danes se beograjska metropolitanska regija (v nadaljevanju BMR) in širša makroregija Beograda (tako kot sta opredeljeni v Prostorskem planu Srbije, sprejetem 1996.), po dolgoletni razvojni diskontinuiteti srečujeta s številnimi problemi. Opazno je poslabšanje in nazadovanje vseh vitalnih sistemov mesta, propadanje grajenega tkiva in infrastrukturnih sistemov ter resna ogroženost gospodarske, socialne, naravne in kulturne substance vse makroregije. Dalje, zaradi nereguliranih zemljiškopravnih odnosov in nekaterih absurdnih zakonskih rešitev, podedovanih iz obdobja socializma, je še vedno nemogoče vzpostaviti pravo tržno zemljiško politiko, ki bi sama po sebi bila eno bistvenih regulacijskih orodij obvladovanja in upravljanja mesta. Posledica pomanjkanja ustreznih upravljavskih in nadzornih mehanizmov $\mathrm{v}$ preteklosti je neplanska in nezakonita graditev, deloma $v$ ožjem ter intenzivno in »organizirano « v širšem prostoru mesta. Toda vsebinska problema sta bila neprepoznana vizija razvoja metropolitanske regije in pomanjkanje vsaj nakazane strategije, še zlasti kar zadeva premišljene planske odgovore na velike spremembe v demografskem in socialnem prestrukturiranju, ki so se zgodile v zadnjem desetletju 20. stoletja. Še več, nezadostno ozaveščen odnos političnih nosilcev moči do pomembnosti koordiniranega razvoja in ohranjanja splošno uveljavljenega sistema norm in vrednot nam nalaga pogumnejše ravnanje pri odpravljanju napak in pomanjkljivosti iz preteklosti.

Zato je nujno opredeliti nekaj prednostnih strateških ciljev BMR glede na evropske razsežnosti razvoja. Cilji so:

- nova opredelitev in postavitev metropolitanske regije $\mathrm{v}$ odnosu do evropskega, makroregionalnega in regionalnega zaledja oziroma njen položaj in vloga/funkcija v evropskem in balkanskem okviru;

- vzpostavitev učinkovite in vzdržne prometne infrastrukture in ustrezne vključitve $v$ evropsko prometno omrežje (TENs in TINA);

- dekoncentrirana koncentracija in prestrukturiranje, izboljšanje in razmestitev ekonomskih struktur zaradi povečanja ekonomske konkurenčnosti metropolitanske regije; 
- varovanje in izboljšanje naravnih osnov, kulturnih posebnosti in krepitev metropolitanske identitete;

- profiliranje beograjske metropolitanske regije s specializiranimi gospodarskimi dejavnosti, še posebno storitvenimi dejavnostmi za jugovzhodno Evropo.

\subsection{Nova opredelitev in postavitev BMR v odnosu do evropskega,} makroregionalnega in regionalnega zaledja oziroma njen položaj in vloga/ funkcija $v$ Evropi in na Balkanu

Državne meje so čedalje manj ovire in omejitve, zlasti $\mathrm{Z}$ vidika prostorskega razvoja. Nasprotno, monopol države nad infrastrukturno, izobraževalno, kulturno in socialno oskrbo družbe bo vedno ožji v korist javnozasebnih združevanj in partnerstev, ki bodo bistveno vplivala na razvoj BMR. Proces globalizacije ne samo gospodarskih, temveč vseh družbenih dejavnosti, ki bodo kmalu in mnogo intenzivneje prodrle predvsem v obravnavano območje, bo vplival na zaostritev lokacijske konkurenčnosti v regiji, vendar jo hkrati potegnil v ostro tekmovanje s podobnimi regijami v sosednjih državah. V jugovzhodni Evropi lahko pričakujemo postopno oblikovanje t. i. storitvenih in industrijskih grozdov (vsekakor nižjega ranga kot v severozahodni Evropi) s težko razločljivimi funkcijami storitev in industrije, ki se bodo ob vzpostavitvi regionalnih omrežij tudi medsebojno spodbujale. Pomembnost, vpliv in ekonomska privlačnost Beograda $\mathrm{v}$ tem delu Evrope so se v zadnjem desetletju na žalost bistveno zmanjšali. Tako je bil na kartah Evropske unije iz leta 1991 predstavljen kot člen v verigi evropske mreže mest. [1] Takrat je Beograd vsekakor bil metropola velike Jugoslavije s prek 20 milijoni prebivalcev in bruto družbenim proizvodom prek 3000 USD po prebivalcu.

Današnje izhodišče je zelo spremenjeno; razpoložljive ekonomske, socialne in kulturne osnove sorazdejane, celotna podoba pa iznakažena.

Medtem se je že leta 1993 nemško ministrstvo za prostorsko planiranje, graditev in urbani razvoj hitro odzvalo na spremenjene politične okoliščine, vendar očitno na nezadostno utemeljene ocene strateške pomembnosti
Beograda na Balkanu, v sklopu prostorskih politik v evropskem okviru dodelilo Beogradu status nacionalne urbane regije s pomembnimi evropskimi funkcijami. [2] Toda ta razvrstitev obsega vrsto nadrejenih položajev:

- globalne urbane regije (London in Pariz);

- možne globalne urbane regije (Moskva);

- mednarodne urbane regije (Sankt Peterburg, Rim, Dunaj, Berlin, Randstad (Nizozemska) in mesta Porenja in Porurja);

- možne mednarodne urbane regije (Budimpešta, Praga in Bruselj);

- evropske mestne regije (Lizbona, Barcelona, Marseille, Lyon, Zürich, Milano, München, Hamburg, Manchester in Birmingham, Köbenhavn, Stockholm, Gdansk, Varšava, Krakov, Bukarešta, Atene);

- možne evropske regije (Stuttgart, Luxembourg, Oslo, Sofija).

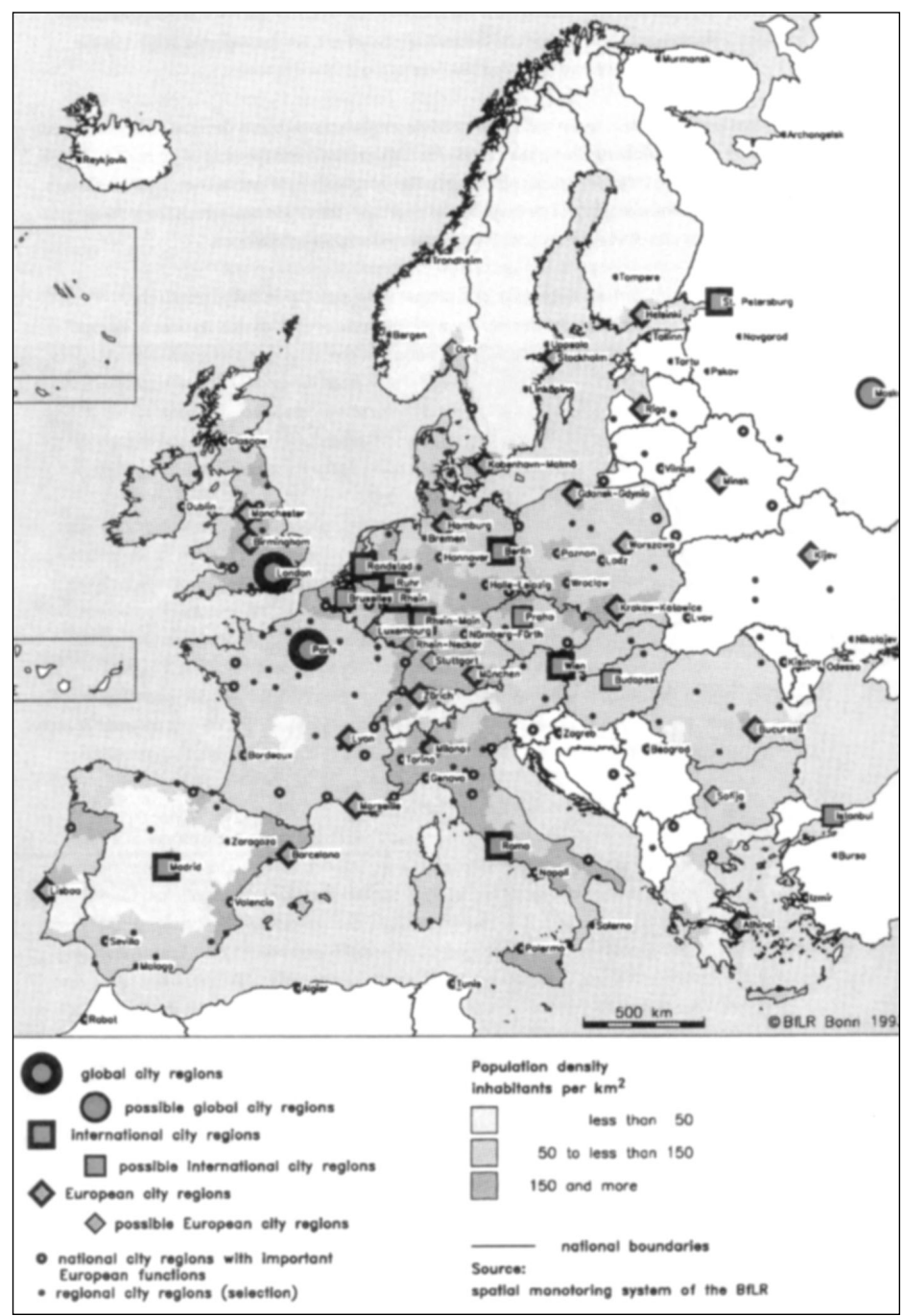

Slika 2: Mestne regije evropskega pomena. 
$\mathrm{V}$ tem ozvezdju evropskih urbanih regij je beograjski dodeljen bistveno nižji rang kot urbanim regijam Dunaja, Budimpešte, Bukarešte in Sofije oziroma enak kot Ljubljani, Zagrebu, Skopju in Solunu.

Nesporno je, da takšne študije nimajo apriorne relevantnosti, temveč so prej izraz trenutnih političnih odnosov ali prizadevanj. Torej, čeprav je bil BMR v samo dveh letih, od leta 1991 do 1993, degradiran za nekaj stopnic in marginaliziran na evropskih kartah, lahko pričakujemo, da mu bosta strateški položaj in dejanski pomen na evropski ravni glede na spremenjene politične odnose kmalu vrnjena. Pa vendar, za vsaj delno rehabilitacijo njegove vloge $v$ jugovzhodni Evropi je nujno prostorsko opredeliti njegovo dejansko vplivno sfero in s korenitimi reformami izboljšati vse potenciale in funkcije, ki imajo evropski in makroregionalni značaj.

Razvoj Beograda se ne more dogajati na mestu niti omejiti le na osrednje območje mesta. Urbanizacija kot prevladujoča družbena težnja vpliva na celotno mrežo mest in naselij v državnem in evropskem okviru in vso regionalno dinamiko. To pomeni, da se bodo prihodnji razvojni procesi dogajali v razponu dolgoročno usmerjenega in usklajenega razvoja evropskih regij, v katerih bo beograjska morala najti svoj dejanski prostor pri uveljavljanju strateškega razvoja mesta s pripadajočim zaledjem.

Ena prednostnih nalog pri doseganju tega cilja je regionalizacija Srbije. BMR bi lahko deloval in se oblikoval kot regija, samo če bi vzpostavili kooperativno in prožno regionalno upravo z ustreznimi planskimi pristojnostmi, ki bi pri ključnih vprašanjih razvoja tesno sodelovala in usklajevala razvojne ter varovalne interese skupaj s sosednjimi regijami. Zato bi bilo priporočljivo osnovati nekakšno skupno koordinacijsko interregionalno plansko telo, v katero bi vključili vse pomembne regionalne in lokalne igralce.

Reforme, potrebne za izvedbo navedenega, so vezane na usklajevanje regionalnih in urbanih politik oziroma planiranja $z$ evropskimi. Za takšno uresničitev bo treba oblikovati nove in neposrednejše oblike sodelovanja, iz katerih bo nastala skupna korist, katere cilj bo zmanjšanje navzkrižnih interesov. $\mathrm{V}$ ta sklop spadata konstruktivno in interesno partnerstvo s sosednjimi in drugimi mesti ter urbanimi regijami Evrope in stalno raziskovanje njihovih izkušenj ter najboljših praktičnih rešitev (best practices) za obvladovanje novih in starih težav. Treba bo torej razviti jasne posvetovalne mehanizme $\mathrm{z}$ vidika evropskega in regionalnega razvoja, ki se bodo kazali v opredeljevanju razvojnih, zakonskih in tehničnih mer.

Glede na dejstvo, da je razvoj BMR prednostnega pomena za skupni razvoj Srbije in njeno rehabilitacijo $v$ mednarodnih okvirih, bo izvajanje strateških ciljev razvoja zahtevalo usklajeno sodelovanje državnih, republiških in lokalnih nosilcev politične moči, ekonomskih igralcev ter vseh drugih nevladnih subjektov, tako da bi s sinergičnimi napori zasnovali inovativne politike in instrumente, namenjene izvedbi temeljite obnove mesta in pripadajočega zaledja. Morda to vsebuje tudi posebno pogodbo med Beogradom kot glavnim mestom s federalnimi ali republiškimi organi, pri čemer bi bila posebna proračunska sredstva namensko usmerjena v uresničitev prednostnih razvojnih ciljev. Takšen dogovor se prikazuje kot pomemben, sploh če upoštevamo potrebo po hitrih ekonomskih in socialnih spremembah, povečanju dinamičnosti in še zlasti vzpostavljanju prometnih in telekomunikacijskih sistemov, skladnih $\mathrm{Z}$ evropskimi standardi. Le odločna politična volja, jasno opredeljene strateške prednosti in konkretni izvedbeni programi lahko BMR omogočijo, da se upre večletni marginalizaciji in se razglasi za najpomembnejše in najperspektivnejše mesto jugovzhodne Evrope.

\subsection{Vzpostavitev učinkovite in vzdržne prometne infrastrukture in primerno vključevanje $\mathrm{v}$ evropsko prometno omrežje (TENs in TINA)}

Usklajena in izboljšana evropska prometna mreža je hrbtenica razvoja sodobne Evrope. Zaradi ugodne geografske lege lahko Beograd dolgoročno postane ena od presečnih točk te mreže (gate city), kar bi bistveno vplivalo na izboljšanje gospodarske lokacijske kakovosti metropole in širšega regionalnega zaledja. Hkrati bi takšno omreženje prispevalo k oblikovanju celovite verige potrebnih logističnih storitev, s tem pa k odpiranju kakovostnih delovnih mest. Ključni pojmi v razpravi o prometnih potencialih BMR in njihovi optimizaciji so intermodalnost/multimodalnost oziroma izboljšana 
možnost izbora medsebojno usklajenih oblik prometa (cestni, tirni in rečni) in interoperabilnost $z$ vidika olajšanja nemotenega prometnega pretoka med državami širše makroregije (usklajeni tirni sistemi, skupni normativi in ustrezna ponudba prometne ponudbe, olajšani in hitrejši postopki na mejnih prehodih idr.). Vzpostavitev trgovinske unije balkanskih držav je pomemben prispevek $\mathrm{k}$ temu cilju.

Pri tem je treba stvarno opredeliti prostorsko-časovne odnose tako do državnega/medmestnega, makroregionalnega in evropskega prostora, kakor tudi znotraj-mestnega. Izdelava napovednega scenarija teh odnosov, zasnovanega na dejanskih in možnih osnovah izboljšanja danih struktur (cest, tirov, ladij, mreže optičnih kablov, kablovskega omrežja idr.), bi bistveno vplivala na opredelitev razvoja metropolitanske regije, vendar mora doseči odziv tudi v prostorskem in generalnem planu Beograda. Pri izboljšanju zdajšnje in načrtovanju nove prometne infrastrukture je nujno slediti načelom vzdržnega razvoja, kar pomeni zavrnitev podvojenih struktur, oziroma doseči funkcionalno specializacijo (pristanišča Beograd, Pančevo in Smederevo), pospeševanje tirnega in rečnega prometa blaga ter reševanje ozkih grl ob zmanjšanju posledic škodljivih emisij.

Svet Evrope na nekakšni splošni ravni dodeljuje jugovzhodni Evropi funkcija prehoda (function of passage) do vzhodnih držav (Rusija, črnomorske države, Turčija in Grčija) in Azije (Bližnji in Daljni vzhod).[3] To območje tako postaja središčna cona za organizacijo sodelovanja med Evropo in Azijo, zlasti kar zadeva mrežo prenosa energije. Tu imajo posebno vlogo transevropske in panevropske prometne mreže (TENs in TINA), iz katerih je povsem jasen interes Evropske unije za omreženje naše države v okolico. Gre predvsem za koridorja VII in X, ki se križata prav pri Beogradu.

Koridor VII ali Donavski koridor je poseben, ker je edini rečni evropski koridor, v katerem je Donava glavna žila prostora CADSES in povezuje številne metropole srednje Evrope $\mathrm{Z}$ Beogradom. V makroregionalni in regionalni razsežnosti igra pomembno vlogo, zlasti v smeri Smedereva, Velikega Gradišta in Golubca vse do nacionalnega parka Džerdap. Potenciali, ki jih Donava ponuja, niso danes niti približno izkoriščeni ne le za intenziv- nejšo plovbo in razvoj pristanišč, temveč tudi $\mathrm{v}$ turistično-rekreativnem in kulturnem smislu. Dve smeri koridorja X (severna k Budimpešti in Dunaju, zahodna k Zagrebu, Ljubljani in Trstu) $\mathrm{z}$ razcepiščem pri Nišu za smeri Solun in Sofijo sta verjetno najbližja, najlogičnejša in najcenejša cestna povezava zahodne, severne in srednje Evrope z Bližnjim in Srednjim vzhodom.

\subsection{Dekoncentrirana koncentracija in prestrukturiranje ter izboljšanje gospodarskih struktur zaradi povečanja gospodarske konkurenčnosti metropole}

Bistveni cilj strategije beograjske metropole je predlog za postopno oblikovanje tistih mrežnih struktur, zlasti funkcionalnih, informacijskih, telekomunikacijskih in infrastrukturnih, ki bodo omogočile Beogradu neposrednejšo povezavo s svojim pripadajočim zaledjem in nasprotno. To bi pripomoglo h kakovostnejši izboljšavi lokacijske konkurenčnosti tega območja. Vzpostavitev in pospeševanje močnejšega in medsebojno bolj povezanega in usklajenega regionalnega tržišča bi tudi povečala celotno ekonomsko moč beograjske metropolitanske regije. Pri tem mislimo predvsem na ustvarjanje novih in krepitev zdajšnjih medsebojnih učinkov zaradi graditve skladnega učinkovitega sistema prepletenih proizvodnih in storitvenih verig. BMR s svojim prebivalstvenim potencialom, zaradi katerega je najmočnejše nacionalno tržišče tako za potrošno blago kakor tudi široko ponudbo storitvenih dejavnosti, bi moral tudi $\mathrm{v}$ nacionalnem okviru doseči pomembnejši donos zaradi velikosti tržišča.

Deregulacija oziroma izrazito tržna usmerjenost v bližnji prihodnosti je tesno povezano s prihajajočimi strukturnimi spremembami in bo imela neposredne prostorske posledice, kar pomeni, da bo usodno vplivala na prostorskofunkcionalne odnose med mestom in regionalnim zaledjem. Da bi se BMR usmerila h koncentrirani dekoncentraciji je nujno, da se nekatere funkcije, morda celo posamezne institucije, preselijo v subregionalna in bližnja regionalna središča. Tukaj mislimo na novo opredelitev pomena pristanišča v Beogradu, ki bi lahko zadržalo status potrošnega pristanišča, okrepili pa bi položaj pristanišč v Pančevu in Smederevu. Zaradi 
lastnih potencialov se občini Grocka in Mladenovac ponujata za območji skupnih con živilske industrije, občina Sopot pa se lahko strateško razvije $\mathrm{v}$ pomembno naravno turistično obmestno cono.

Pri krepitvi konkurenčnega položaja igrajo posebno vlogo nova polja tehnologije, predvsem nove informacijske in komunaikacijske tehnologije, biotehnologija in farmacija, mikroelektronika in tehnologija novih gradiv oziroma celovito inovacijsko vzdušje. Da bi Beograd v svojem neposrednem mednarodnem/balkanskem okolju nadomestil izgubljeno, je nujno s posebnimi programi in finančnimi ureditvami spodbujati tiste visokošolske ustanove in inštitute, ki lahko prispevajo k ustvarjanju osnove znanja in inovacij za podporo prestrukturiranja regionalnega gospodarstva in dviga splošne prostorske zanimivosti. Nekatere bi lahko bile neposredno v proizvodnih conah.

\subsection{Ohranjanje in izboljšanje naravnih osnov ter kulturnih posebnosti in krepitev identitete metropole}

BMR je zapleten sistem ekoloških, socialnih, ekonomskih in kulturnih potreb. Ker tržni

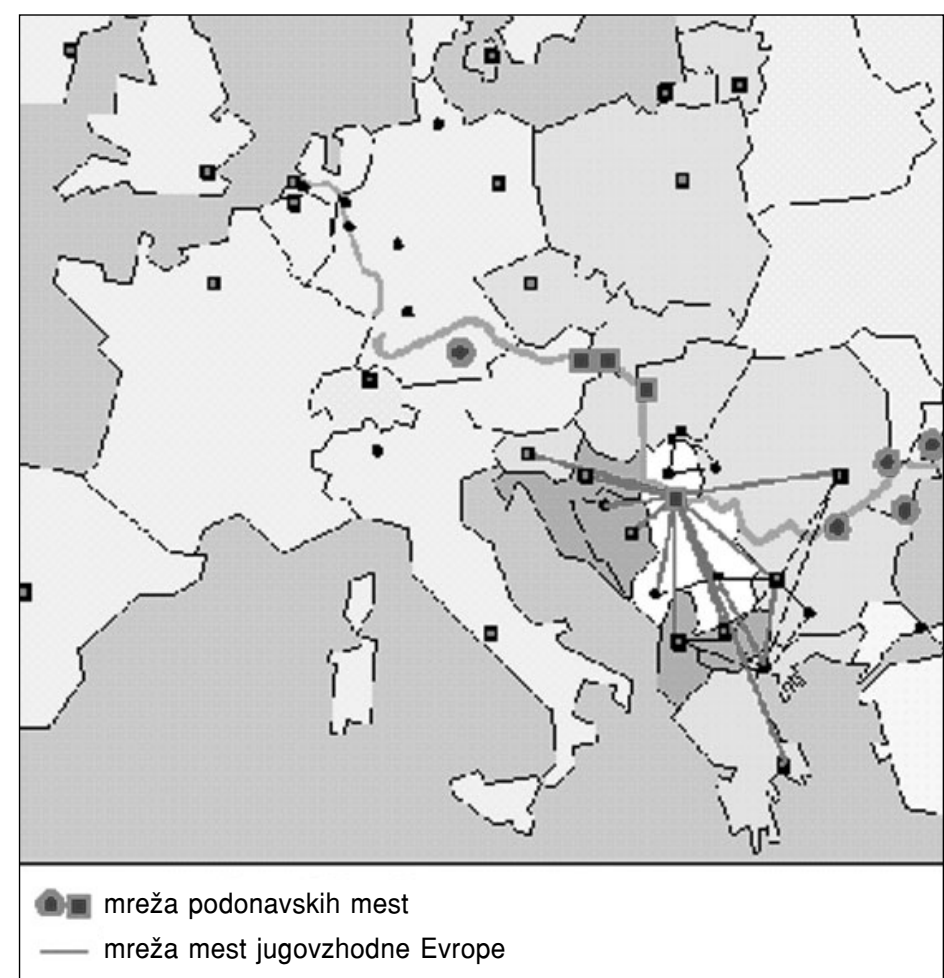

Slika 3: Oblikovanje mreže mest v Podonavju in državah zahodnega Balkana. mehanizmi sami po sebi pogosto dajejo prednost interesom, ki so navzkrižni ekološkim kakovostim prostora, bodo nujni izrecna politična volja in ustrezni nadzorni mehanizmi za usklajevanje morebitnih konfliktnih namembnosti prostora in zagotovitev usklajenega in vzdržnega razvoja.

S prav malo vizionarstva je mogoče predvideti, da bosta ekološko zdravo okolje in ustrezen politični odnos do tega vprašanja prispevala k prav tistim okvirnim razmeram, ki bodo omogočile koncentracijo gospodarskih središč in pripadajočih raziskovalnih dejavnosti. Nekdanje intenzivno in neracionalno izkoriščanje zemljišč, prav tako tudi neustrezno vzdrževanje in neučinkovit sistem zaščite ter tudi neozaveščen ter neodgovoren odnos uporabnikov so dosegli, da se BMR srečuje $\mathrm{z}$ resno degradiranimi prostori in predeli narave. Za ustavitev tako neugodnega razvoja in dajanje prednosti sinteznemu cilju, tj. kompaktnemu mestu, je treba oblikovati pravne razmere, ki bodo zagotovilo, da bodo povzročevalci ogrožanja naravnega okolja in predelov tudi plačniki njihove revitalizacije. Na splošno mesto s svojimi potrebami po zemljiščih in skupnimi dinamičnimi dejavnostmi najakutneje ogroža naravno oklje. Zato se je smiselno zgledovati po evropski praksi in ponotranjati ekološke stroške ter omogočiti takšne finančne ureditve, ki bodo zagotovile ustrezne sklade za sanacijo in vzdrževanje naravnih prostorov mesta ter okolice. Najprej bo treba oceniti trenutne razmere življenjskega okolja BMR glede na seštevek vseh škodljivih učinkov.

Da bi Beograd izkoristil vse svoje razpoložljive naravne potenciale in v zadostni meri oživil zapuščene zelene in odprte površine, je treba imeti pred očmi vrsto pomembnih elementov. Predvsem so to zaščita in izboljšanje bregov Save in Donave, oblikovanje privlačnih poti za pešce in kolesarje, rekreacijskih prostorov, parkov, igrišč, zaščitenih zelenih con in javnih prostorov pa tudi oživljanje in boljše povezovanje $z$ obmestnimi turističnimi možnostmi.

Ob pregledu vseh dejanskih potencialov Beograda, ki ga bodo oblikovali v evropsko privlačno in konkurenčno mesto, je treba omeniti vlogo pospeševanja in izboljšave kulturne dediščine, kulturnih vsebin in mednarodnih kulturnih prireditev, s katerimi lahko pritegne pozornost. 
Ustrezen kulturni pečat Beograda bo zasnovan na kakovosti urbane ponudbe - mestnih javnih prostorov in urbanih rekreacijskih površin, na ulični scenografiji in negovanih specifičnih ambientalnih vrednosti. V primerjavi s podobno velikimi evropskimi mesti morda nima zavidanja vrednega stavbarskega bogastva, toda niti to, kar ima, ni ustrezno zavarovano ali vzdrževano. Nesporno pa so potenciali za izboljšanje raznovrstnih in slikovitih ambientalnih celot, ki bi ob primernem sodelovanju meščanov in finančni pomoči zainteresiranih donatorjev lahko bili predmet pilotnih projektov, usklajenih $\mathrm{s}$ splošno strategijo prenove mesta. Takšni projekti in obravnava, ki bi zajeli koordinirane selektivne posege javno-zasebnih ureditev, namenjenih prenovi, so mogoči le, če ustanove, pristojne za zaščito kulturne dediščine, spremenijo svoja stališča in sprejmejo aktivne in prožne metode zaščite. Po drugi strani bo pogosto problematična estetika hibridnih obrobij, razsutih in heterogenih naselbinskih sklopov ter obmestnih naselij, značilnih za BMR, zahtevala takšne strategije, ki bodo dajale prednost povezovanju, dopolnitvam in vmeščanju struktur mešane namembnosti ter jih pospeševale. Samo tako bo mogoče sproščati urbani duh in urbano kulturo ter spodbujati raznovrstne urbane vsebine, ki po oblikovnih in funkcionalnih odlikah zadovoljevanja dnevnih potreb ne bodo zaostajale za tistimi v osrednjih mestnih območjih.

\subsection{Profiliranje beograjske metropole s specializacijo gospodarskih dejavnosti, še posebno storitvenih}

Glede na dejstvo, da se Beograd s precejšnjo zamudo vključuje v evropsko urbano tekmo, kjer se vsa mesta v svojih regionalnih, državnih in mednarodnih okoljih bojujejo za čimboljši položaj in vpliv, je nujno spoznati dejanske možnosti in opaziti tiste razvojne niše, ki v jugovzhodni Evropi še niso povsem zapolnjene. Na žalost je Beograd nekatere bitke že izgubil, namreč tiste, ki so povezane z umeščanjem sedežev večjih tujih podjetij, korporacij in evropskih organizacij v tem delu Evrope. Praga, Varšava in še posebno Budimpešta, ki je največji sosednji tekmec, so se tako že izoblikovale. Zato bo treba za BMR postaviti jasno mejo oziroma hierarhijo v razvoju ponudbe ekonomskih dejavnosti, še zlasti storitvenih. Samo s ciljno in premišljeno specializacijo funkcij, ki imajo evropski/balkanski značaj, lahko Beograd ustvarja svojo evropsko prepoznavnost.

Takšna strateška opredelitev zahteva v kratkoročni projekciji naslonitev na zdajšnje strukture in potenciale in povezovanje na tiste funkcije, ki jih je Beograd uspešno ponujal med največjo blaginjo. Predvsem so to kongresne in sejemske funkcije, ki so lahko spodbuda za prenos tehnologij in inovativnih proizvodnih programov ter ekonomsko povezovanje tega dela Evrope.

Beograd je nesporno eno najzanimivejših in plodovitejših kulturnih središč Balkana. V nekaterih poljih svoje kulturne in ustvarjalne pojavnosti pomembno bogati kulturno diverziteto Evrope. Naložbe v kulturo in izboljšanje kakovostnih kulturnih vsebin in ponudbe morajo biti kratkoročni in dolgoročni strateški cilj, ki bo omogočil BMR, da se pravilno postavi v mrežo mest jugovzhodne Evrope.

Svetovna medijska tematizacija Beograda zadnjega desetletja je bistveno prispevala $\mathrm{k}$ oblikovanju svojevrstne, v marsičem sprevržene slike tega mesta. Nesporno dejstvo je, da Beograd vzbuja zanimanje Evropejcev in je že uvrščen v ponudbo evropskega mestnega turizma. Glede na njegove potenciale in zelo specifično neformalno dinamiko je nujno strateško nalagati v bogatitev turistične ponudbe središča mesta, vendar tudi obmestnih naravnih predelov in celot, kar bo celovito izboljšalo zanimivost BMR.

\section{Nekaj konkretnih operativnih predlogov za povečanje konkurenčnosti beograjske metropole}

$\mathrm{V}$ regionalni tekmi postaja vse pomembnejša kakovost lokalnih uprav in upravljavskih mehanizmov zato je nujno radikalno izboljšati kakovost javne administracije. Ta vsebuje povečanje učinkovitosti administrativnih postopkov in izboljšanje storitvenega značaja javnega sektorja. Hkrati je treba oblikovati postopke za ciljno in dejavno sodelovanje prebivalstva ter drugih zainteresiranih skupin $\mathrm{v}$ procesih planiranja, vendar tudi izvajanja planov. Če se ne vzpostavi naveza planerja, 
meščanov, politike in gospodarstva, bo zelo težko okrepiti najšibkejši člen v dozdajšnjem planiranju in izvajanju planskih predlogov.

Dolgoročno bo vzdržni razvoj BMR odvisen od usklajenega, kompromisnega in zavestnega stališča ne le planerske skupnosti, temveč vseh igralcev celovitih družbenih dejavnosti, vendar tudi individualnega vedenja posameznika, zasnovanega na novih vrednostnih normah. Samo tako se lahko in mora tolmačiti pogosto ponavljano maksimo: razmišljati globalno in delovati lokalno.

Da bi se zagotovila primerna koordinacija in obravnava različnih zahtev $\mathrm{v}$ zvezi z načrtovanjem poslovnih naložb, bi mesto moralo podobno drugim evropskim mestom (npr. Dunaj) izdati t. i. »marketable business site package «, torej paket poslovnih lokacij, v katerem bi bil seznam privlačnih razvojnih lokacij za različne namene na vsem metropolitanskem območju. Na osnovi skladno oblikovanih meril mora takšen paket lokacij dati oceno vsakega posameznega prostora. Kakovostna ocena lokacij mora vsebovati informacije o dostopnosti, morebitni etapnosti graditve, razpoložljivi infrastrukturi in pregled/oceno investicijskih učinkov v odnosu do urbane ekonomike. Vzporedno takšnemu podvigu bi bilo treba razviti ustrezen nabor orodij za nadzor lokacij poslovne graditve.

Končno, s podmeno, da velja splošno soglasje o strateškem cilju, ki se nanaša na povečanje konkurenčnosti BMR, in jasni opredelitvi njegove urbane prepoznavnosti, je treba razmišljati tudi o vrsti premišljenih potez za podporo dejavnosti, ki jo izvajajo v večini evropskih in svetovnih metropol, a to je »marketing mesta «.

Dr. Borislav Stojkov, Univerza v Beogradu, Geografska fakulteta, Inštitut za prostorsko planiranje,

E-pošta: stojkov@gef.bg.ac.yu

Mag. Snežana Subotić, Univerza v Beogradu, Geografska fakulteta, Inštitut za prostorsko planiranje, E-pošta: stas@net.yu

\section{Opombe}

[1] Spatial Perspectives in Europe, str. 144.

[2] Spatial Perspectives in Europe, str. 28.

[2] Guiding Principles for Sustainable Spatial Development of the European Continent (CEMAT, Sept. 1999.)

\section{Viri in literatura}

ESTIA-European Space and Territorial Integration Alternatives, Spatial Policy Integration Framework of Southeast Europe, Mart 2000.

Guiding Principles for Sustainable Spatial Development of the European Continent (1999) CEMAT.

Metropolitan Region Vienna (2000) Urban Planning Bureau Vienna, Municipal Departmant 18, Stadtplanung Nr. 33 A, Dunaj.

Spatial Perspectives in Europe, Ministry of Housing, Spatial Planning and Environment, National Spatial Planning Agency, Januar 2000.

Strategy Plan for Vienna, Urban Planning Bureau Vienna, Municipal Departmant 18, Beč 2001.

Strategy Report, Metropolitan Region Berlin-Brandenburg, Gemeinsame Landesplanung Berlin-Brandenburg, Potsdam, Decembar 1999.

Verflechtungsstrukturen im Metropolenraum BerlinBrandenburg, Brandenburgische Technische Universität Cottbus, 2000.

VISION PLANET-Strategies for Integrated Spatial Development of the Central European Danubian and Adriatic Area, Guidelines and Policy Proposals, January 2000. 